\title{
MIGRATION, THE PERCEPTION OF SECURITY RISKS AND MEDIA INTERPRETATION FRAMEWORKS IN CROATIA AND HUNGARY
}

\author{
Vlatko Cvrtila, Marija Slijepčević, Tomislav Levak
}

\begin{abstract}
Although they are the most vulnerable group of people, immigrants are often perceived as a threat, with immigration and terrorism issues put under a common denominator. Political discourse and mass media are contributing factors, which, when framing migrants as a threat and emphasizing the connection with terrorism in their reporting, can affect the perception of public safety risks. Framing migrants as a terrorist risk has a negative impact on migration-related policies, changing focus from humanitarian towards security issues. The European Union's migration policy is humanitarian, but it is reconsidered by individual member states defining migration as a risk. In these countries, measures to prevent terrorism include the acceptance of restrictive immigration policies, e.g. in Hungary. In the process of securitization, migrants are interpreted as a risk and threat to the survival of traditional identity values.

This problem is analysed through examples of Hungary, a country with an exceptionally restrictive migration policy, and neighbouring Croatia which was perceived as a transitional country for migrants and refugees on their way West during the European migration crisis in 2015 and 2016, much like Hungary. For this purpose, several components are considered: the results of longitudinal Eurobarometer surveys that can determine public opinion changes in EU member states, the trends and results of the Hungarian referendum on migration quotas from October
\end{abstract}


2016, and the selected research and analysis of trends and media coverage of this issue in media. It is an attempt to determine whether and to what extent the public, political authorities and media in Croatia and Hungary referred to "unintentional" or "forced migrants" as the negative nonEuropean Other, during the European migration crisis.

Keywords: Croatia, Hungary, media framing, migrations, perception of risk, terrorism 


\section{INTRODUCTION}

Interpreting the unknown as a danger and threat is a very common occurrence in human civilization, commonly defended against by using instruments that ought to increase security, making people willing to invest their own freedom into it. This results in disturbing the balance between freedom and security, which is particularly important in maintaining a democratic and liberal political order. Previous experiences from political history point to the dangers of security dominating over freedom, as the consequences are increasing repression, violence, creation of hostilities, and imposing those paradigms opposed to human principles and values on society. It seems that the 2015 migration crisis in Europe reopened the space for dominance of security over freedom, and the imposition of repressive over humane instruments.

Over the past twenty years, international migration has become one of the most important security issues in Europe and North America. Liberal democracies develop discourses in which migration flows are interpreted and shaped in the context of human rights with a view to avoiding racism and xenophobia (Freeman, 2001). Hence, humanitarian approaches dominated in Western liberal states and multiculturalism models were developed. The terrorist attack on the United States on 11 September 2001 contributed to an increase in terrorist threats worldwide and the creation of the culture of fear ${ }^{[1]}$. After coordinated attacks via abducted passenger flights on several selected targets in the United States, which killed nearly 3,000 people, a number of terrorist attacks occurred in Western Europe, and the fear of terrorism especially increased after the events of the last several years. As a consequence of these developments, there has been an increase in anti-immigrant attitudes in the public in many Western countries and demands for more restrictive immigration

[1] The Culture of fear phenomenon occurred much earlier, along with the expansion of mass media (Zekić Eberhard and Levak 2015, 446), but today this term is most often used to describe the social state of consciousness after the 2001 US terrorist attacks. The creator of the concept of culture of fear is considered to be British sociologist Frank Furedi who explained it in 2009 in the book "Invitation to terror". In it he portrayed how „fear politics”, especially after $9 / 11$, creates an atmosphere in which citizens are irrationally afraid of an unknown threat (Furedi 2009, 121). This phenomenon is not only related to the United States or, later, Western European countries: Zekić Eberhard and Levak conducted a survey in 2015 which showed that from April 1998 to the end of 2014, the number of contents with features of various fears and (potential) threats in the headlines of leading daily newspapers in Croatia increased between four and eight times, depending on the period. 
policies (Barber, 2010; Hall, 2010; Hollinger, 2011). Immediately after the terrorist attacks in the United States and Europe, a link was made between immigration and insecurity. Immigration in these cases was associated with terrorism and the increasing risk of terrorist attacks. The extraordinary measures and the security approach to immigration show how much this issue is increasingly associated with the activity of a country's security system, and less and less with a humanitarian approach.

An exploration of this phenomenon came from the position of European immigration policy due to migratory waves in 2015 and 2016. The analysis examined how public opinion changed and, in particular, how one of the most prominent and most severe anti-immigration policies (Hungary) influenced the attitudes of that society. It also examined the presence a manner of reporting that could have an impact on the perception of the public in Hungary and Croatia - primarily by media framing and information selection. Namely, the presentation of immigrants as a risk may have an impact on the implementation of restrictive immigration policies and the emergence of racism and xenophobia.

\section{MIGRANTS AS A THREAT TO NATIONAL SECURITY}

The refugee wave in the second decade of the $21^{\text {st }}$ century affected Europe in 2011 as "the consequence of multi-year transitional processes in the Middle East and North Africa within the so-called Arab Spring" (Tadić et al. 2016, 15; Jurišić et al. 2017, 40). Its peak occurred in the period from 2014 to 2016, due to the exodus of refugees from war events in Syria. According to Banulescu-Bogdan and Fratzke (2015), there were three basic routes for refugees and migrants coming into Europe. The first, central Mediterranean route, leading across Italy and Malta, was the main refugee route in 2014, with around 120,000 people coming to Europe between January and September 2015. The second, East Mediterranean route (Greece and Aegean Sea) was the leading route for refugees and migrants in 2015 and it is estimated that up to 350,000 people entered Turkey from Greece in September. The third route is called the West Balkan Route, and according to estimates of experts, more than 155,000 people entered Hungary from Serbia in the first nine months of 2015. The people 
who come to Europe via this route are divided into two main groups: economic migrants (mostly Albanians and Kosovo residents) and refugees (Banulescu-Bogdan and Fratzke, 2015; Jurišić et al. 2017, 40).

Faced with a large migrant wave, and under the pressure of the public and radical political actors, the governing structures of Western European countries began to gradually introduce certain measures to limit the influx of migrants with a view to full control of these processes, all to reduce the danger to Europe because migrants were interpreted as those who bring many risks for European societies. This is their direct dehumanization, where they are not viewed as people in distress, but as a security risk, whose reduction requires repressive measures are creating barriers to movement across European borders. Migrants were interpreted as a homogeneous group in order to conceal their heterogeneity and blur the fact that these were individual human destinies. Such an approach limits the design of policies that should promote and support the humane approach to all who have migrated due to endangerment to human life and dignity.

The perception of immigrants as a threat to national security has developed especially during and after a major migration wave in the second half of 2015 towards Europe. It was already present in European discourse, but developed especially after terrorist attacks, or after viewing immigration as an increased risk of terrorist attacks. And the main "tools" of the European Union for immigration management, such as the Schengen Agreement and the Dublin Declaration, interpret it as a security problem (Huysmans 2000, 756; Huysmans 1995, 53).

Much like immigrants are associated with terrorism, they are linked to an increasing crime rate, which affects the perception of public security, although research in several EU countries has shown a weak correlation between immigration and the rise of crime (Wang 2012, 743). The question arises as to why immigrants in the EU are linked to security or insecurity issues? 


\subsection{Migrants and Endangering the Identity of the Community}

According to the Copenhagen School of Security Studies, the concept of social security should primarily address issues of collective identity protection. Ole Weaver $(1993,23)$ clarifies social security as "the ability of society to persist in the preservation of its fundamental character in conditions of changed circumstances and possible or current threats." Buzan, Wever and de Wilde $(1998,121)$ believe that there are three categories of threats to societies: migration, horizontal and vertical competition. Consequently, migrations appear as a phenomenon that citizens of a state associate with endangering their cultural, linguistic, religious or national identity. In this regard, national values and identity features appear as a referential object whose security is being threatened. Migrants are treated as a risk and a threat to national identity to be protected, and in the process of securitization, the attitude towards migrants is formed, describing them almost exclusively through the threat of national identity attributes. Immigrants described as "Other" ${ }^{[2]}$ and "different" that must be prevented from coming into a society, and if they come, then policies of national identity protection must be developed, aimed at their exclusion from social dynamics (Huysmans 2000, 758).

Huysmans $(2000,758)$ considers that framing immigrants as a threat to social security "reproduces the political myth of the homogeneity of national communities or Western civilization that existed earlier (in the process of establishing national European communities/states, op.a.) and can be re-established through the exclusion of those migrants we identify as cultural aliens." Immigration securitization is a simple process because it relies on the already present myths about a special national identity to be protected from all threats, making restrictive policies socially acceptable.

[2] The concept of the "Other" in philosophy, and particularly phenomenology, has been the subject of many eminent European philosophers since the $18^{\text {th }}$, notably George Wilhelm Friedrich Hegel and later psychoanalysts like Jacques Lacan or philosophers of ethics such as Emmanuel Levinas. They approached and observed the concept of the Other in various ways, so it changed its meaning over the years. After having been regarded for decades as a constituent and inseparable part of the same human being that is generally opposed, but again in correlation with the Self (Hegel and Miller 1977, 98-99), in the $20^{\text {th }}$ century the term Other and its variant Otherness are also related to other people and groups of people, most often not in a positive context. In his book "Orientalism" published in 1978, Palestinian-American intellectual Edward W. Said gave the most famous definition of the Other, relevant to the issue of migrants and refugees. Said concluded that orientalism is "Western knowledge of the Eastern world", where the Orient (consisting of people in Asia, North Africa and the Middle East) is depicted as irrational, mentally weak and feminized, non-European, Other, which is opposed to a rational, mentally strong and male West, primarily Europe (Said, 1978). 
In doing so, societies do not take into account that the act of securitization of immigration can be more threatening for those same societies than immigration, since xenophobia and racism develop accordingly, which directly causes social disintegration and strengthens a radical political platform that can easily be turned against other "others" and "the different", thus causing long-term social instability.

\subsection{Securitization, Definition of Threat and Extraordinary Measures}

Securitization theory is a framework for analysing processes in which an issue is presented as a question of security (Weaver, 1995). This occurs in cases where securitization providers (most often the state) pose an issue as an existential threat to a reference object (state, society, individual groups, etc.). In issues that are securitized, the initiator of this process (the state) most often requires the implementation of extraordinary measures to minimize or eliminate threats as soon as possible. When a state gets the opportunity to take extraordinary measures, the powers of certain institutions may be temporarily suspended because their operation through regular procedures and jurisdiction could "decelerate" the action aimed towards the presented threats. This opens up space for the strengthening of authoritarian forms of government as well as for populist concepts that weaken democratization processes and own institutions, which in the long-term may present a major challenge for states.

Once it has securitized a certain issue, the state has the option of using extraordinary measures outside regular procedures, thus creating special security regimes. They act towards immigrants as a risk, applying extraordinary measures and procedures, which are often inhumane and restrictive to immigrants. Such action is approved by the majority in the community (since that supports the action of protecting the identity of the community), and society is gradually accustomed to the normality of applying such measures. The media, especially those under the control of the governing structures, are involved in spreading the discourse related to questions of insecurity. 


\section{THE ROLE OF MEDIA IN PERCEPTION OF RISK}

The mediatisation of insecurity associated with immigrants creates a perception of a strong connection between immigration and criminality and terrorism. One of the most commonly used ways is media framing. This process, as explained by Entman (1993), essentially involves selecting and highlighting: framing means selecting certain aspects of reality and highlighting them by promoting a certain problem, a causative interpretation, a moral evaluation, or a recommendation for resolution (Entman, 1993, Slijepčević and Fligić 2018, 34). Numerous authors talk about a mutual relationship between media frames and frames in which the public thinks. A message is transmitted that can be summarized in the following conclusion: more migrants, less security (or more insecurity). By framing immigrants through discourses of insecurity the media contribute to an affective epidemic (Grossberg, 1992) through which states justify and rationalize their restrictive policies and procedures.

In 2004 Goldberger analysed how American political weekly publications (Time, Newsweek, U.S. News \& World Report) presented immigrants before and after the terrorist attacks on 9/11. Media coverage moving from a positive tone emphasizing their contribution to the United States to a highly negative, almost racist one, can shape immigration policy. In the period prior to the terrorist attack on New York, immigrants were predominantly represented as needed, laborious workers and useful necessities for the economic system; economic issues and Latin American immigrants are predominant topics. After the terrorist attacks, immigrants in the media were mostly represented as unwanted or those to be feared due to terrorism threats or for aiding and sheltering terrorists. Legal regulation and security failures at border control are highlighted as the causes of the problem. Political topics are overwhelmingly dominant over economic ones, and most news reports are about Arab terrorists.

Lecheler, Bos and Vliegenthart (2015) have explored how media framing affects the respondents' immigrant-related emotions, assuming that exposure to media framing can cause emotional reactions in individuals. The sample consisted of 715 Dutch citizens who were exposed to four previously defined frames: the emancipation frame, multiculturalism, 
assimilation and victimization. The hypothesis that positive frames in the media enhance a positive attitude towards immigrants and vice versa was confirmed, e.g. the emancipation and multiculturalism frames caused the most intense emotional reactions of satisfaction, compassion, enthusiasm and hope.

Conklin Frederking (2012) conducted a comparative analysis of immigration policy framing and pointed out that after $9 / 11$ immigration was viewed through the prism of terrorism in the US and Canadian media (analysing the period between 1990-2009). The problem of migrant perception is observed through a triple prism; political discourse in congressional debates (whether immigration is spoken of within the context of terrorism, economics or human rights), media content (whether it is related to terrorism or the economy) and the consequences on immigration policy (institutional, bureaucratic and legislative changes). Both the US and Canada indicated increased negative attitudes towards immigration in public opinion polls.

Similar research has also been carried out on the topic of asylum seekers, considered to as the most vulnerable category of people in the world. In 2005, Van Gorp analysed the content of eight Belgian newspapers, examining how Belgian media cover the issue of asylum seekers using deductive research, in which only two frames were chosen: victims or intruders. His research, which encompassed 1,489 news articles, proved that the frame of asylum seekers as intruders was more dominant.

Innes (2010) analyses asylum seekers in the UK through state policy, statements by politicians and mass media content. Referring to the Copenhagen School of Security Studies, he notes that asylum seekers are defined as a "collective that shares criminal attributes and presents a threat to physical security" (Innes 2010, 463). He also points out that immigrants are portrayed as an economic threat and a threat to national identity. The patterns of that portrayal, given the large migrant movements, have been present throughout the European Union since 2015, which is when the continuous implementation of research and analysis of treatment of migrants and refugees in the media began in Croatia. 


\subsection{Media Treatment of Migrants and Refugees in Croatian Media}

Faced primarily with issues of growing nationalism and xenophobia in Hungary, Zekić Eberhard and Levak (2016) analysed ways in which the four most widely read daily and informative internet portals in Croatia (direktno.hr, index.hr, net.hr and tportal.hr), of different political orientations, followed events in Hungary related to the refugee crisis. These portals were first among the Croatian media in reporting on this issue, so the analysis was conducted in a one-month period from 15 September to 15 October 2015, at the peak of the European migration crisis. The findings indicated that events in Hungary were predominantly affirmatively reported on only by the politically right-wing portal direktno. $h r$ (15 out of 21 texts were positively intoned). The other three moderate or left-wing portals mostly framed their articles in a critical or negative tone (ranging from 55 to 75\%), particularly criticizing the controversial moves of Hungarian authorities, such as erecting a barbed wire at its borders with Serbia and Croatia, and the harsh deportation of migrants (Zekić Eberhard and Levak 2016, 982).

The aim of the research conducted by Jurišić, Vesnić Alujević and Bonacci (2017) was to determine how often and in what manner the media analysed the refugee crisis in Croatia, what was the media and political agenda and during which period it changed in relation to migrants and refugees, and how the public reacted to reporting on the refugee crisis. The analysis of 12,721 articles and 416,374 comments on these articles on the refugee crisis in eight online Croatian news portals from 15 September 2015 to 15 March 2016 showed that the media agenda partially coincided with the public's agenda. Since the refugee wave hit Croatia, the number of articles in the media grew rapidly from day to day, peaking in October 2015 with a total of 3,094 published articles on these eight sites, followed by varying conditions. During the research period, the media changed their perspectives, using the word "refugees" at the beginning of the crisis, ending with the moderated term "migrant". Among the 11 thematic "clusters", the largest and most polarized public debate was triggered by the nationally "tinted" topic of the mutual border blockade between Croatia 
and Serbia, eliciting the greatest number of comments (Jurišić et al. 2017, 53-54).

Slijepčević and Fligić (2018) also conducted an analysis of media monitoring of the refugee crisis in Croatia, but with emphasis on framing. The content analysis included a total of 702 articles, published in four Croatian media (two daily newspapers, Jutarnji list and Večernji list, and two news portals, index.hr and tportal.hr) in the period from 16 to 22 September 2015 (the first week of the migration crisis) and from 15 to 21 November 2015 (after the Paris terrorist attack), detecting patterns of interpretation frameworks. Refugees and migrants were mostly shown as victims rather than threats, with emotionally strong photographs and emphasis on warm and personal human stories, or positively intoned articles on migrants and refugees, particularly prevalent in the first week (Slijepčević and Fligić 2018, 46).

Apart from examining the selected research and media analyses, citizens' attitudes and the development of the situation can be traced through longitudinal Eurobarometer surveys that compare and measure trends within EU member states. 


\section{CHANGES IN PUBLIC OPINION - EUROBAROMETER SURVEYS}

Through the observed time periods research indicates there are significant changes in public attitudes towards terrorism and immigration of persons from outside the European Union. Interesting answers are also yielded regarding the most important issues facing the EU and its members.

Figure 1. Public opinion on immigration of people from outside the $E U^{[3]}$ : all member states (11/2014 - 05/2016)

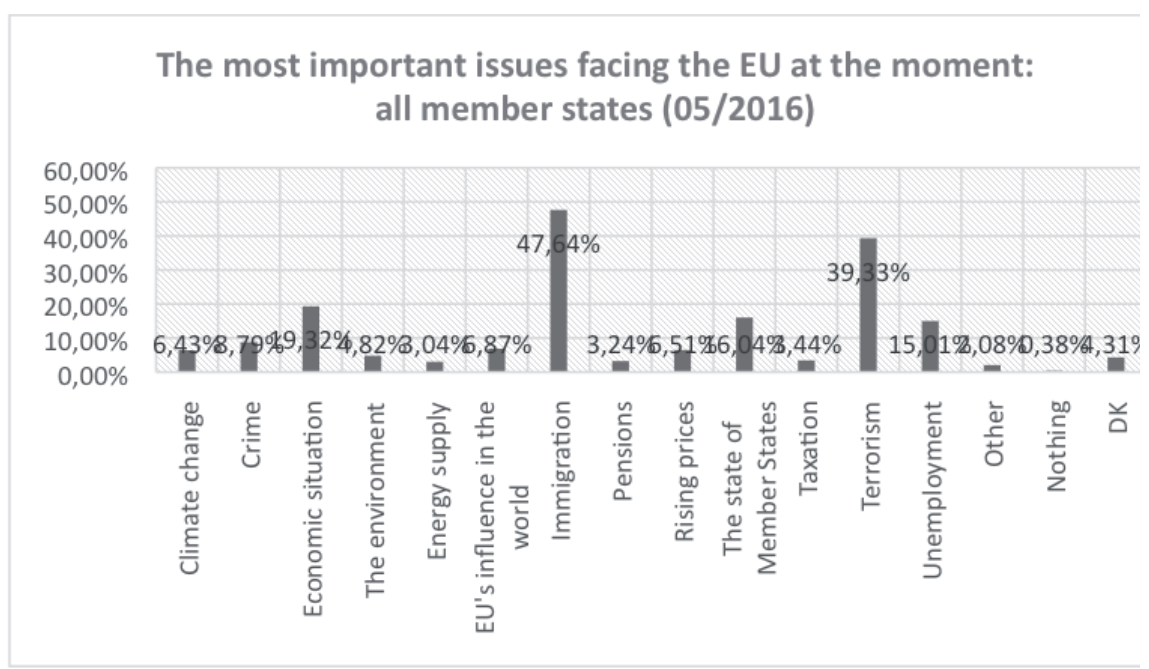

Source:

http://ec.europa.eu/COMMFrontOffice/publicopinion/index.cfm/Chart/getChart/ chartType/lineChart//themeKy/59/groupKy/279/savFile/646 (12 January 2019)

Figure 1 shows that the most common answer of respondents in all EU member states to the question whether the claim "Immigration of people outside the EU" causes positive or negative feelings, is "quite negative" (35.15 to 37.45\%), with "very positive" (from 6.17 to $6.81 \%$ ) least represented, as measured between November 2014 to May 2016.

[3] Question asked: „Please tell me whether each of the following statements evokes a positive or negative feeling for you. Immigration of people from outside the EU.“ 
Figure 2. Most important issues facing EU at the moment: all member states (05/2016)

The most important issues facing the EU at the moment: all member states (05/2016)

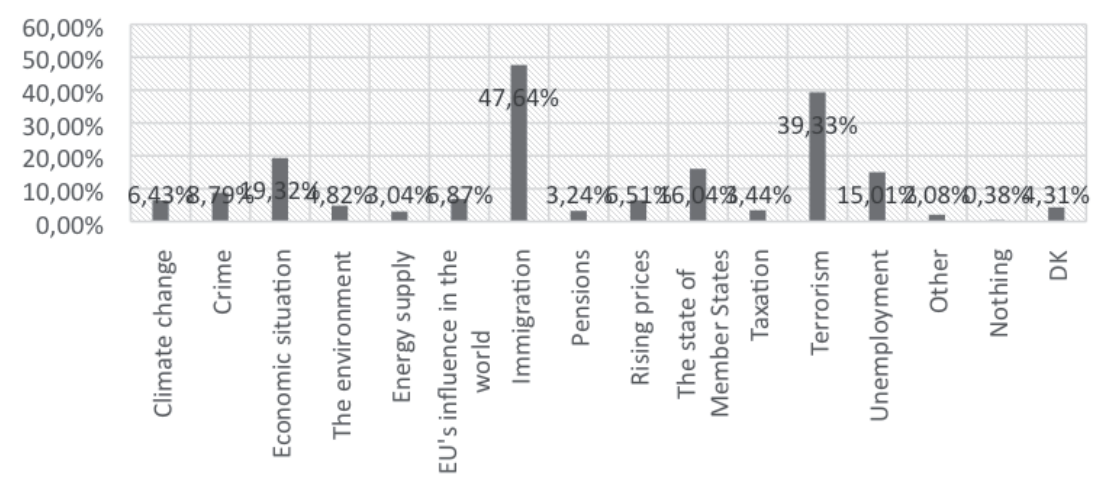

Source:

http://ec.europa.eu/COMMFrontOffice/publicopinion/index.cfm/Chart/getChart/ themeKy/31/groupKy/188 (14 January 2019)

Asked about the biggest problems facing the European Union at this time, the prevailing response "immigration" (47.64\%) and "terrorism" (39.33\%) occurred in May 2016. When viewing the question in a historical perspective (Table 1), since the start of measuring this question (May 2011) to the end of 2014, the predominant responses in all EU members were: the biggest problem is the economic situation, followed by unemployment and the public finances of member states. 
Table 1. Most important issues facing EU: all member states

$$
(05 / 2011-5 / 2016)
$$

\begin{tabular}{|c|c|c|c|c|c|c|c|c|c|c|}
\hline & 6.5 .2011 & $\underline{12.5 .2012}$ & 3.11 .2012 & 10.5.2013 & 2.11 .2013 & 31.5 .2014 & 8.11 .2014 & 16.5 .2015 & 7.11 .2015 & 21.5 .2016 \\
\hline Climate change & $9,23 \%$ & $3,28 \%$ & $3,46 \%$ & $3,46 \%$ & $4,28 \%$ & $5,00 \%$ & $6,70 \%$ & $5,62 \%$ & $6,36 \%$ & $6,43 \%$ \\
\hline Crime & $16,42 \%$ & $5,84 \%$ & $5,76 \%$ & $7,48 \%$ & $7,61 \%$ & $7,00 \%$ & $6,89 \%$ & $7,79 \%$ & $8,46 \%$ & $8,79 \%$ \\
\hline Economic situation & $82,20 \%$ & $54,23 \%$ & $52,84 \%$ & $48,10 \%$ & $44,65 \%$ & $39,00 \%$ & $32,72 \%$ & $26,85 \%$ & $20,68 \%$ & $19,32 \%$ \\
\hline The environment & $11,76 \%$ & $3,35 \%$ & $3,20 \%$ & $3,27 \%$ & $4,18 \%$ & $5,00 \%$ & $5,61 \%$ & $4,77 \%$ & $4,64 \%$ & $4,82 \%$ \\
\hline Energy supply & $13,12 \%$ & $3,95 \%$ & $3,76 \%$ & $3,27 \%$ & $4,32 \%$ & $6,00 \%$ & $6,48 \%$ & $4,02 \%$ & $2,69 \%$ & $3,04 \%$ \\
\hline EU's influence in the world & $11,60 \%$ & $6,85 \%$ & $6,59 \%$ & $6,55 \%$ & $6,28 \%$ & $8,00 \%$ & $8,78 \%$ & $7,14 \%$ & $5,78 \%$ & $6,87 \%$ \\
\hline Immigration & $38,90 \%$ & $8,79 \%$ & $8,39 \%$ & $10,24 \%$ & $16,47 \%$ & $21,00 \%$ & $24,03 \%$ & $37,62 \%$ & $58,00 \%$ & $47,64 \%$ \\
\hline Pensions & $7,06 \%$ & $2,92 \%$ & $2,74 \%$ & $2,86 \%$ & $3,74 \%$ & $3,00 \%$ & $3,58 \%$ & $3,67 \%$ & $3,12 \%$ & $3,24 \%$ \\
\hline Rising prices & $32,28 \%$ & $15,35 \%$ & $15,52 \%$ & $12,99 \%$ & $12,15 \%$ & $10,00 \%$ & $9,84 \%$ & $9,35 \%$ & $7,04 \%$ & $6,51 \%$ \\
\hline The state of Member States public finances & $43,01 \%$ & $33,53 \%$ & $31,80 \%$ & $30,31 \%$ & $26,44 \%$ & $25,00 \%$ & $24,78 \%$ & $22,50 \%$ & $16,84 \%$ & $16,04 \%$ \\
\hline Taxation & $7,81 \%$ & $5,37 \%$ & $5,68 \%$ & $5,88 \%$ & $6,63 \%$ & $5,00 \%$ & $5,66 \%$ & $4,49 \%$ & $3,40 \%$ & $3,44 \%$ \\
\hline Terrorism & $25,39 \%$ & $5,13 \%$ & $4,42 \%$ & $7,22 \%$ & $5,65 \%$ & $6,00 \%$ & $10,80 \%$ & $17,48 \%$ & $24,90 \%$ & $39,33 \%$ \\
\hline Unemployment & $45,35 \%$ & $32,15 \%$ & $35,87 \%$ & $37,78 \%$ & $35,87 \%$ & $34,00 \%$ & $28,70 \%$ & $23,95 \%$ & $17,27 \%$ & $15,01 \%$ \\
\hline Other & $1,51 \%$ & $0,76 \%$ & $0,64 \%$ & $0,85 \%$ & $0,85 \%$ & $2,00 \%$ & $1,82 \%$ & $1,69 \%$ & $1,95 \%$ & $2,08 \%$ \\
\hline Nothing & $0,46 \%$ & $0,46 \%$ & $0,37 \%$ & $0,29 \%$ & $0,50 \%$ & $1,00 \%$ & $0,71 \%$ & $0,63 \%$ & $0,69 \%$ & $0,38 \%$ \\
\hline Don't know & $5,79 \%$ & $4,40 \%$ & $4,28 \%$ & $4,87 \%$ & $4,99 \%$ & $7,00 \%$ & $6,62 \%$ & $6,28 \%$ & $4,28 \%$ & $4,31 \%$ \\
\hline
\end{tabular}

Source:

http://ec.europa.eu/COMMFrontOffice/publicopinion/index.cfm/Chart/getChart/ chartType/lineChart//themeKy/31/groupKy/188/countries/EU/periodStart/052011/ periodEnd/052016 (21 December 2018)

The table further shows that since 2015, immigration took first place, with terrorism coming into second place by the end of the same year. The previous three economic problems visible fell out of the respondents' focus, for example, in May 2016, fear of terrorism reached 39\%, economic situation $19 \%$ and unemployment $15 \%$ of responses. It is possible to view each of the questions mentioned in each European Union member based on the same survey with equally representative samples. For further analysis, public opinion in Hungary will be taken into particular consideration.

\subsection{Hungarian Referendum on Migrant Quotas and Aggressive Anti-Immigration Campaign}

Hungary is one of the European countries that significantly felt the consequences of the European migration crisis, and Hungarian Prime Minister Viktor Orbán gained prominence through restrictive policies and actions, the largest of which was the construction of a 175-kilometer long wire fence on the southern border with Serbia. Aggressively opposing common European policy and refugee management, he also led the issue of mandatory quotas to the Court of Justice in Luxembourg. In February 2016, Prime Minister Viktor Orbán announced that the 
Hungarian government would hold a referendum on whether to accept the proposed EU quota for migration, pointing out that it is no secret that the Hungarian government will reject quotas and run a campaign against its adoption. The announcement of the referendum caused numerous public commentaries, from the opposition to the leaders of EU institutions who called the referendum an ideological move that opposes a common policy; they called for humanitarian aid and assistance to the needy, and it was constantly emphasized that Hungary was to accept only 1,294 asylum seekers according to the joint plan.

The referendum was held on 2 October 2016 with the question: "Do you want the European Union to be able to prescribe the mandatory settlement of non-Hungarian citizens in Hungary even without the consent of Parliament?" [4] The referendum was attended by 3,643,055 citizens, or $44.04 \%$ of all registered voters, hence not exceeding the mandatory $50 \%$ threshold. 98.36\% actually voted "no" and thus endorsed the government plea for rejecting the EU plan. Interestingly, 224,668 invalid ballots, the highest number in Hungary's political history, are the result of an active campaign against the referendum. ${ }^{[5]}$

$B B C$ News Europe editor Katya Adler commented on the BBC: "On the one hand, Viktor Orbán led a prominent, expensive and relentless anti-EU and anti-migrant referendum campaign but failed to persuade most Hungarians to vote. On the other hand, those who did vote sided with him almost unanimously, allowing him to trumpet that a higher percentage of Hungarians voted against EU migrant quotas than voted for EU membership 13 years ago."[6]

It is estimated that the information campaign was worth $€ 10$ million in budget money, according to the Hungarian daily newspaper Nefeleadsag ${ }^{[7]}$, and other Hungarian media reported on sums exceeding $€ 30$ million. The most prominent part of the campaign belonged to posters in public spaces and ads in media with messages: "Did you know that the Paris terror attacks were carried out by immigrants?"; "Did you know that nearly one million immigrants want to come to Europe from Libya alone?", "Did you know that over 300 people were killed in terrorist attacks

[4] National Election Office. http://www.valasztas.hu/en/ref2016/481/481_0_index.html (20 January 2019)

[5] National Election Office. http://www.valasztas.hu/en/ref2016/481/481_0_index.html (20 January 2019)

[6] BBC. http://www.bbc.com/news/world-europe-37528325 (17 January 2019)

[7] BBC. http://www.bbc.com/news/world-europe-37310819 (17 January 2019) 
in Europe since the beginning of the migration crisis?"; "Did you know that since the start of the immigration crisis, harassment of women has increased in Europe?", "Did you know? Brussels plans to settle a whole town's worth of illegal immigrants in Hungary?"[8] and other ads. ${ }^{[9]}$ The Government's methods throughout the campaign was also the organization of numerous public forums in rural environments involving ministers, state secretaries, parliamentarians, security specialists and journalists, promoting prominently anti-immigrant and anti-Muslim attitudes. ${ }^{[10]}$ This also practically encouraged the development of Islamophobia ${ }^{[11]}$ among Hungarian citizens.

In the last few days of the campaign, Viktor Orbán gave numerous interviews to pro-government media broadcasters - Origo.hu, M1 national channel, Catholic Radio, TV2, Magyar Idök - in which he stressed that he loves his country ${ }^{[12]}$ and did not want to see it changed under external orders, that he wants everything to remain the same and that Hungarians have the right to decide who they want and who they do not want to live in their country. ${ }^{[13]}$

The Human Rights Watch (HRW) announced that the Hungarian government spent $€ 16$ million disseminating misinformation on immigrants and encouraging xenophobia, for example, through an 18page booklet sent to 4.1 million Hungarian households. ${ }^{[14]}$ The HRW

[8] BBC. http://www.bbc.com/news/world-europe-37310819 (17 January 2019)

[9] Similar posters were designed by the opposition in favor of a boycott of the referendum: "Did you know one million Hungarians want to emigrate to Europe?", "Did you know that the average Hungarian will have seen a UFO sooner than a refugee in his/her lifetime?", "Did you know? The perpetrators in most corruption cases are politicians?", "Did you know? During the Olympics, the biggest danger to Hungarian participants came from foreign competitors?" and others.

[10] Index.hu.https://index.hu/belfold/2016/09/13/uj_szinten_a_kampany_kover_laszlo_nekirontott_egy_ migrans_focisztarnak/ (20 February 2019)

[11] According to Isanović, "Islamophobia now qualifies as a new form of Western European racism and antiSemitism, which is primarily based on the escalation of ethnic cultural and religious differences between Europeans and Muslims. Literally, Islamophobia means an unfounded fear of Islam and Muslims" (Isanović 2013, 46; Zekić Eberhard and Levak 2016, 971). Islamophobia can be observed from several aspects, but in its essence, it is defined "as a kind of social anxiety about Islam and Muslims" (Gottschalk and Greenberg 2007, 11). Isanović believes this term probably appeared in the UK in the late 1980s "and from the beginning, this word is associated with hatred and fear of The Other" (Isanović 2013, 46). Numerous experts state that the culmination of Islamophobia at the time was recorded after the terrorist attacks in the US on 11 September 2001, while a new strong rise of this kind of fear in Europe was recorded during the migration crisis in 2015 and 2016 (Zekić Eberhard and Levak 2016).

[12] "I love this country, and I do not want to see anyone change it under orders from outside". (Origo.hu, September 2016)

[13] "We do not allow them [EU institutions] to take away from us the right of exclusive control over the question of who we want to live with here in Hungary and who we don't want to live with. I love my homeland and I want it to remain just the way it is [...]". (M1 national channel, September 2016)

[14] Human Rights Watch. https://www.hrw.org/news/2016/09/13/hungarys-xenophobic-anti-migrant-campaign (20 January 2019) 
described the booklet as a vehicle for instilling fear into Hungarian citizens, by portraying asylum seekers and migrants as a danger to the future of Europe, including sentences such as "Forced Deal Endangers Our Culture and Tradition". Migration is associated with an increase in terrorism, and it also mentions the non-existent "no-go" areas in European cities with a large population of migrants (London, Paris, Berlin) where authorities have supposedly lost control, and which are now characterized by the absence of law enforcement.

How this national policy influenced citizens' attitudes is observable via measurements of public opinion.

Figure 3. Public opinion on immigration of people from outside the EU: answers in Hungary (11/2014 - 05/2016)

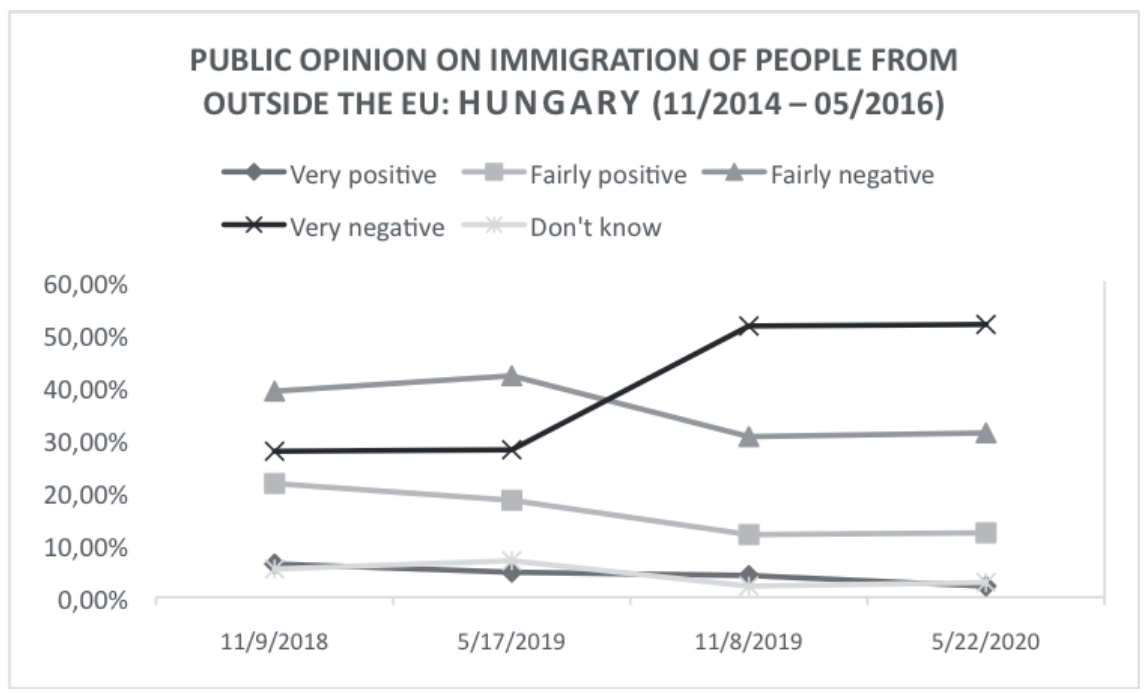

Source:

http://ec.europa.eu/COMMFrontOffice/publicopinion/index.cfm/Chart/getChart/ chartType/lineChart//themeKy/59/groupKy/279/countries/HU/periodStart/112014/ periodEnd/052016 (12 January 2019)

Figure 3 portrays how respondents in Hungary answered the question about feelings caused by immigration of persons from outside the EU. The dominant responses are "very negative" and "fairly negative", while "very positive" is least represented. There was a noticeable "leap" in 
Hungary regarding the very negative position: in May 2015 it comprised $27.96 \%$ of answers, but in the two following surveys it reached over $50 \%$ (51.44\% in November 2015 and 51.73\% in May 2016). In the same period, the percentages for "very positive" and "fairly positive" decreased.

Table 2. Most important issues facing the EU: answers in Hungary (2011 - 2016)

\begin{tabular}{|c|c|c|c|c|c|c|c|c|c|c|}
\hline & 6.5 .2011 & 12.5 .2012 & 3.11 .2012 & 10.5 .2013 & 2.11 .2013 & 31.5 .2014 & 8.11 .2014 & 16.5 .2015 & 7.11 .2015 & 21.5.2016 \\
\hline Climate change & $5,68 \%$ & $3,88 \%$ & $4,60 \%$ & $4,66 \%$ & $4,72 \%$ & $5,94 \%$ & $6,17 \%$ & $6,69 \%$ & \begin{tabular}{|r|}
$4,79 \%$ \\
\end{tabular} & $6,03 \%$ \\
\hline Crime & $7,66 \%$ & $5,14 \%$ & $5,29 \%$ & $7,74 \%$ & $9,19 \%$ & $12,95 \%$ & $11,16 \%$ & $10,60 \%$ & $11,47 \%$ & $9,65 \%$ \\
\hline Economic situation & $51,91 \%$ & $50,62 \%$ & $51,20 \%$ & $47,84 \%$ & $43,60 \%$ & $34,24 \%$ & $31,65 \%$ & $26,41 \%$ & $15,48 \%$ & $11,68 \%$ \\
\hline The environment & $5,11 \%$ & $2,53 \%$ & $1,49 \%$ & $1,83 \%$ & $3,20 \%$ & $3,64 \%$ & $4,65 \%$ & $3,88 \%$ & $3,19 \%$ & $4,60 \%$ \\
\hline Energy supply & $10,76 \%$ & $7,90 \%$ & $6,50 \%$ & $9,05 \%$ & $7,35 \%$ & $8,75 \%$ & $10,34 \%$ & $7,59 \%$ & $4,91 \%$ & $3,66 \%$ \\
\hline EU's influence in the world & $4,70 \%$ & $6,23 \%$ & $5,64 \%$ & $7,58 \%$ & $7,53 \%$ & $10,37 \%$ & $9,98 \%$ & $7,26 \%$ & $6,32 \%$ & $8,07 \%$ \\
\hline Immigration & $10,17 \%$ & $6,31 \%$ & $6,95 \%$ & $7,20 \%$ & $10,37 \%$ & $19,16 \%$ & $18,05 \%$ & $42,92 \%$ & $67,93 \%$ & $66,66 \%$ \\
\hline Pensions & $5,30 \%$ & $4,89 \%$ & $2,22 \%$ & $2,55 \%$ & $5,35 \%$ & $4,32 \%$ & $7,10 \%$ & $4,84 \%$ & $4,11 \%$ & $4,23 \%$ \\
\hline Rising prices & $15,06 \%$ & $13,42 \%$ & $14,48 \%$ & $12,37 \%$ & $12,52 \%$ & $12,15 \%$ & $11,19 \%$ & $9,37 \%$ & $5,85 \%$ & $3,13 \%$ \\
\hline The state of Member States public fin: & $28,48 \%$ & $46,47 \%$ & $49,09 \%$ & $44,34 \%$ & $35,57 \%$ & $30,77 \%$ & $29,15 \%$ & $25,64 \%$ & $14,46 \%$ & $13,39 \%$ \\
\hline Taxation & $2,25 \%$ & $3,76 \%$ & $3,42 \%$ & $2,41 \%$ & $3,30 \%$ & $3,97 \%$ & $6,74 \%$ & $3,30 \%$ & $2,91 \%$ & $1,52 \%$ \\
\hline Terrorism & $6,92 \%$ & $3,77 \%$ & $3,24 \%$ & $5,12 \%$ & $5,84 \%$ & $6,97 \%$ & $6,63 \%$ & $19,89 \%$ & $33,88 \%$ & $46,82 \%$ \\
\hline Unemployment & $33,07 \%$ & $31,63 \%$ & $32,60 \%$ & $27,99 \%$ & $31,99 \%$ & $28,87 \%$ & $27,99 \%$ & $17,73 \%$ & $12,54 \%$ & $7,67 \%$ \\
\hline Other & $0,38 \%$ & $0,64 \%$ & $0,49 \%$ & $0,55 \%$ & $0,40 \%$ & $1,42 \%$ & $0,72 \%$ & $0,71 \%$ & $0,24 \%$ & $1,18 \%$ \\
\hline Nothing & $0,00 \%$ & $0,54 \%$ & $0,16 \%$ & $0,00 \%$ & $0,16 \%$ & $0,80 \%$ & $3,58 \%$ & $0,27 \%$ & $0,16 \%$ & $0,17 \%$ \\
\hline Don't know & $2,04 \%$ & $2,50 \%$ & $1,75 \%$ & $4,45 \%$ & $2,22 \%$ & $3,51 \%$ & $2,85 \%$ & $3,24 \%$ & $2,21 \%$ & $2,60 \%$ \\
\hline
\end{tabular}

Source:

http://ec.europa.eu/COMMFrontOffice/publicopinion/index.cfm/Chart/getChart/ chartType/lineChart//themeKy/31/groupKy/188/savFile/805 (14 January 2019)

Responding to the question on the most important issues facing the European Union in May 2016 (Table 2), the answer immigration was in first place in Hungary with $67 \%$ (the average for all EU respondents was $48 \%$ ), while terrorism reached $47 \%$ (39\% for all members), indicating that Hungarian citizens are considerably more concerned about these issues than citizens of other EU member states. Also, in two years, since May 2014, the increase of these responses was drastic: immigration rose from $19 \%$ to $67 \%$, while terrorism grew from $7 \%$ to $47 \%$. 
Table 3. Most important issues facing Hungary (2005 - 2016)

\begin{tabular}{|c|c|c|c|c|c|c|c|c|c|c|c|}
\hline & 9.5.2005 & 6.9.2006 & 10.4 .2007 & 25.3.2008 & 1.6.2009 & 5.5 .2010 & 12.5.2012 & 10.5 .2013 & 15.3.2014 & 28.2.2015 & 21.5.2016 \\
\hline Crime & $22,63 \%$ & $22,52 \%$ & $23,21 \%$ & $37,31 \%$ & $15,81 \%$ & $32,52 \%$ & $22,66 \%$ & $12,19 \%$ & $12,91 \%$ & $9,46 \%$ & $10,42 \%$ \\
\hline Economic situation & $27,01 \%$ & $23,96 \%$ & $20,00 \%$ & $39,53 \%$ & $41,79 \%$ & $79,70 \%$ & $69,82 \%$ & $32,81 \%$ & $29,25 \%$ & $21,87 \%$ & $19,27 \%$ \\
\hline The education system & $7,19 \%$ & $7,30 \%$ & $9,00 \%$ & $17,14 \%$ & $6,84 \%$ & $15,53 \%$ & $15,47 \%$ & $7,90 \%$ & $8,19 \%$ & $10,14 \%$ & $8,62 \%$ \\
\hline Government debt & & & & & & & $38,06 \%$ & $15,16 \%$ & $12,74 \%$ & $12,36 \%$ & $10,02 \%$ \\
\hline Health and social security & $16,57 \%$ & $14,86 \%$ & $16,43 \%$ & $34,85 \%$ & $13,52 \%$ & $30,47 \%$ & $23,09 \%$ & $11,37 \%$ & $13,41 \%$ & $16,54 \%$ & $16,18 \%$ \\
\hline Immigration & $13,87 \%$ & $21,28 \%$ & $14,91 \%$ & $21,27 \%$ & $9,32 \%$ & $18,01 \%$ & $15,40 \%$ & $9,77 \%$ & $10,58 \%$ & $18,32 \%$ & $28,20 \%$ \\
\hline Pensions & $10,79 \%$ & $9,85 \%$ & $12,09 \%$ & $24,27 \%$ & $8,64 \%$ & $21,73 \%$ & $18,56 \%$ & $9,15 \%$ & $9,96 \%$ & $11,57 \%$ & $12,92 \%$ \\
\hline Rising prices, inflation, cost of living & $15,73 \%$ & $16,78 \%$ & $18,41 \%$ & $75,02 \%$ & $21,12 \%$ & $39,93 \%$ & $46,82 \%$ & $19,59 \%$ & $20,08 \%$ & $15,53 \%$ & $12,68 \%$ \\
\hline Taxation & $6,68 \%$ & $7,47 \%$ & $8,34 \%$ & $20,02 \%$ & $6,58 \%$ & $17,51 \%$ & $17,82 \%$ & $9,39 \%$ & $11,58 \%$ & $8,87 \%$ & $7,36 \%$ \\
\hline Terrorism & $10,17 \%$ & $14,14 \%$ & $12,24 \%$ & $13,97 \%$ & $4,92 \%$ & $6,95 \%$ & $3,95 \%$ & $2,50 \%$ & $1,96 \%$ & $11,33 \%$ & $16,30 \%$ \\
\hline Unemployment & $50,10 \%$ & $41,50 \%$ & $35,95 \%$ & $51,23 \%$ & $49,39 \%$ & $94,87 \%$ & $90,44 \%$ & $51,41 \%$ & $49,07 \%$ & $42,24 \%$ & $33,07 \%$ \\
\hline
\end{tabular}

Source:

http://ec.europa.eu/COMMFrontOffice/publicopinion/index.cfm/Chart/getChart/ chartType/lineChart//themeKy/42/groupKy/208/savFile/805 (14 January 2019)

A similar question relates to a national-level assessment ("What are the most important issues your country is facing at this time?"). Since 2005, there was a dominant concern regarding unemployment in Hungary, hence in 2010 almost $95 \%$ of answers put it in first place. It remained in first place in 2016 (with only 33\%), but immediately followed by immigration (28\%) and terrorism with $16 \%$ (it reached just 1.96\% in 2014), both of which have been on a significant and steady increase since 2015.

Public opinion surveyors in Hungary have noticed many specifics in changing attitudes of Hungarian citizens. The Publicus Institute highlighted a significant drop in the public's sympathy for migrants and refugees: two thirds of respondents supported them a year ago, now it is only one-third, as the $B B C$ wrote. ${ }^{[15]}$ TARKI, the Hungarian Institute for Social Research, reported that racism and xenophobia reached the highest levels since $1990{ }^{[16]}$ In a survey published in January 2016, only one percent of respondents had a positive attitude towards migrants, and $53 \%$ showed clearly xenophobic attitudes (in 2015, a positive attitude was expressed by $6 \%$, and xenophobic attitudes by $41 \%$ of respondents). The main researcher at TARKI Institute Endre Sik noted that in April 2015, when the government began its anti-immigrant campaign, xenophobia was at a high level.

Another research conducted by Závecz Research in September 2016 showed that $70 \%$ of respondents believed that the inflow of refugees

[15] BBC. http://www.bbc.com/news/world-europe-37310819 (17 January 2019)

[16] Euobserver. https://euobserver.com/migration/134363 (17 January 2019) 
increases the risk of terrorism ${ }^{[17]}$. The above-mentioned research is a clear indicator of the attitudes of citizens who are exposed to an aggressive political and media campaign.

\section{CONCLUSION}

Of the most prominent terrorist attacks of the newer era, starting with $9 / 11$ in USA (11 September 2001), immigration around the world as well as in Europe is mostly observed through the anti-terrorism agenda. Governments have changed immigration policies by linking immigration with terrorist threats and other security risks. Immigrants are linked to crime and are shown as a threat to public security. Immigration policy was once viewed in non-security categories, and instruments that legally governed entry and stay in the territory of a state were applied. The situation is different today, with the process of securitization of immigration also being a contributing factor, transforming the issue from an ordinary legal to a pronouncedly security-related one. Securitization has contributed to viewing immigration as a security issue, i.e. a question on which the preservation of the identity of a community depends, inter alia. Political elites are prone to having such issues securitized because it allows them to act outside usual procedures, e.g. to act accordingly to a state of emergency, resulting in a suspension of legal procedures.

The referendum on immigrant quotas in Hungary, organized in October 2016, showed that the local political elite is ready to employ various instruments to portray immigration as a threatening phenomenon, and immigrants as people endangering the identity of the Hungarian community and ultimately the survival of the nation. The Hungarian society was divided between those who supported the referendum and the intentions of the ruling elite to gain support for a restrictive immigration policy and those who thought it was a destructive intent strengthening xenophobic and racist discourses, which could have serious political consequences for Hungary in the future. Although the ruling elite did not receive support in the referendum, its approach to the campaign, the

[17] Hungarian Spectrum. http://hungarianspectrum.org/tag/zavecz-research-institute/ (15 December 2018) 
framing of members of the elected elite in selected media, and the political messages presenting immigrants as a security threat all resulted in an increase in intolerance, racism and xenophobia never previously recorded in public opinion polls in Hungary.

On the other hand, although certain preconditions existed the traditionalism of Croatian society, the hermeticism, the low level of education and strong religious affiliation of the populace and the fact the conservative political option held power more frequently (Slijepčević and Fligić 2018, 46) - there was no serious increase of fear of the unknown "Others" during the migration crisis in Croatia, at least judging by public appearances of government representatives and the available public opinion responses. In most Croatian media (except those at the extremeright side of the spectrum), as indicated by results of several media research surveys, there was a prevalence of reports in which migrants and refugees appeared in a positive or neutral light. Although it is difficult to prove direct correlation, it can be assumed that this kind of mood is at least partly the result of the fact that at the moment the European migration crisis reached Croatian borders, the government reacted to the situation in a moderate and humane manner, and a part of Croatian citizens expressed empathy due to the refugee experiences that they themselves, their family or neighbours had during the Homeland War in the 1990s. 


\section{REFERENCES}

Banulescu-Bogdan, N., and Fratzke, S. 2015. Europe's Migration Crisis in Context: Why Now and What Next? Migration Policy Institute. 24 September: http://www.migrationpolicy.org/article/europe\%E2\%80\%99smigration-crisis-context-why-now-andwhat-next (20 January 2019).

Barber, T. 2010. 'Tensions unveiled'. The Financial Times 16 November: 11. Buzan, B., Wæver, O., and de Wilde, J. 1998. Security: A New Framework for Analysis. Boulder, CO: Lynne Rienner.

Conklin Frederking, L. 2012. 'A comparative study of framing immigration policy after 11 September 2001.' In Policy Studies 33 (4): 283-96.

Entman, R. M. 1991. 'Framing U.S. Coverage of International News: Contrasts in Narratives of the KAL and Iran Air Incidents.' In Journal of Communication 41 (4): 6-27.

Entman, R. M. 1993. 'Framing: Toward Clarification of a Fractured Paradigm.' In Journal of Communication, 43 (4): 51-58.

Freeman, M. 2001. Freedom or security: protecting democracy from terrorism. Chicago: University of Chicago Dissertation.

Furedi, F. 2009. Poziv na teror. Zagreb: Naklada Ljevak.

Goldberger, G. 2004. 'Portrayal of Immigrants in Newsmagazines.' In Migracijske i etničke teme 20: 7-27.

Gottschalk, P., and Greenberg, G. 2007. Islamophobia: Making Muslims the Enemy. Lanham \& New York: Rowman \& Littlefield Publishers.

Grossberg, L. 1992. We Gotta Get Out of This Place: Popular Conservativism and Postmodern Culture. New York and London: Routledge.

Hall, B. 2010. 'Sarkozy comes out fighting after rampage in Grenoble.' The Financial Times, 14 August: 4.

Hegel, G. W. F., and Miller, A. V. 1977. In Force and the Understanding: Appearance and the Supersensible World: Phenomenology of Spirit $\left(5^{\text {th }}\right.$ edition), ed. J. Hoffmeister. New York: Oxford University Press. 
Hollinger, P. 2011. 'Opposition grows to multiculturalism.' The Financial Times 17 February: 2.

Huysmans, J. 1995. 'Migrants as Security Problem: Dangers of 'Securitizing' of Societal Issues.' In Migration and European Integration. The Dynamics of Inclusion and Exclusion, eds. R. Miles and D. Thrandhartd, 53-72. London: Pinter Publishers.

Huysmans, J. 2000. 'The European Union and Securitization of Migration.' Journal of Common Market Studies 38 (5): 751-77.

Innes, A. J. 2010. 'When the Threatened Become the Threat: The Construction of Asylum Seekers in British Media Narratives.' International Relations, December 2010 (24): 456-77.

Isanović, N. 2013. 'Islamofobija ili novi oblik suspenzije zapadnoevropskog uma?' In: Uzroci i prevencija islamofobije (zbornik radova), eds. H. Mehtić and I. Pehlić, 43-57. Zenica-Sarajevo: Islamski pedagoški fakultet Univerziteta u Zenici, Centar za dijalog - Vesatija Sarajevo.

Jurišić, J., Vesnić Alujević, L., and Bonacci, D. 2017. 'Stvaranje agendi: slučaj izbjegličke krize u hrvatskim medijima.' In Mediji, novinarstvo i ljudska prava (Zbornik radova 7. regionalne znanstvene konferencije Vjerodostojnost medija „Novinarstvo i ljudska prava“), eds. V. Car, and M. Matović, 39-54. Zagreb: Fakultet političkih znanosti Sveučilišta u Zagrebu, Hanns-Seidel-Stiftung.

Lecheler, S., Bos, L., and Vliegenthart, R. 2015. 'The Mediating Role of Emotions: News Framing Effects on Opinions About Immigration.' Journalism\&Mass Communication Quarterly 92 (4): 812-38.

Said, E. W. 1978. Orientalism. New York: Pantheon Books.

Slijepčević, M., and Fligić, S. 2018. 'Analiza medijskog praćenja izbjegličke krize u Hrvatskoj i interpretacijski okviri (framing).' Suvremene teme 9 (1): $31-48$.

Tadić, J., Dragović, F., and Tadić, T. 2016. 'Migracijska i izbjeglička kriza sigurnosni rizici za EU.' Policija i sigurnost 25 (1): 14-41.

Van Gorp, B. 2005. 'Where is the Frame?' European Journal of 
Communication 20 (4): 484-507.

Wang, X. 2012. 'Undocumented Immigrants as Perceived Criminal Threat: A Test of the Minority Threat Perspective.' Criminology 50 (3): 743-76.

Wæver, O., Buzan, B., Kelstrup, M., and Lemaitre, P. 1993. Identity, Migration and the New Security Agenda in Europe. London: Pinter Publishers

Wæver, O. 1995. 'Securitization and Desecuritization.' In On Security, ed. R. D. Lipschultz. New York: Columbia University Press.

Zekić Eberhard, N., and Levak, T. 2015. 'The Culture of Fear in Croatian Printed Media.' In Communication Management Forum 2015: Reconciling the Traditional and Contemporary - The New Integrated Communication (proceedings), eds. D. Verčič, D. Jugo, and L. Ciboci, 444-62. Zagreb: Edward Bernays College of Communication Management.

Zekić Eberhard, N., and Levak, T. 2016. 'The Phenomenon of Rising Nationalism and Xenophobia in Hungary in the Context of the 2015/2016 Refugee Crisis and its Reflection in Croatian Media.' In Third International Scientific Conference 2016: Social Change in the Global World (proceedings), 967-88. Shtip: Center for Legal and Political Research, Faculty of Law, Goce Delcev University. 